Актуальні проблеми розвитку економіки регіону. Вип 16. T.2

7. Nosova, O.V. "Investment attractiveness of the enterprise." Stratehichni priorytety, vol. 1 (12), 2007, pp. 120-126.

8. Pyroh, O.V. Scientific and methodological principles of evaluation and regulation of investment activity in the industrial sector of the region, Ph.D. Thesis. Dnipro, Organization of management, planning and regulation of the economy, 2005.

9. Strokovych, H.V. The choice of enterprise investment strategy, Ph.D. Thesis. Kharkiv, Kharkivskyy derzhavnyy ekonomichnyy universytet, 1999.

10. Hrynova, V.M., and M.M. Novikova. Enterprise management in terms of development. Kharkiv, KHDEU, 2003.

11. Yeleyko, Ya.I. Yeleyko, O.I., and K.YE.Rayevskyy. Investments, risk, forecast. Lviv, Lvivskyy bankivskyy instytut, 2000.

УДК 336:338

doi: 10.15330/apred.2.16.170-178

\title{
НАПРЯМИ ПІДВИЩЕННЯ ФІНАНСОВОЇ СТІЙКОСТІ ПІДПРИСМСТВ В УМОВАХ НЕЗАЛЕЖНОГО РЕГІОНУ
}

\author{
Уманський державний педагогічний університет імені \\ Павла Тичини, \\ Міністерство освіти і науки України, \\ кафедра фінансів, обліку та економічної безпеки, \\ вул. Садова, 2, м. Умань, \\ 20300, Україна, \\ тел.: 067-7729730, \\ e-mail:melnichyk_yuliya@ukr.net
}

\begin{abstract}
Анотація. Стаття «Напрями підвищення фінансової стійкості підприємств в умовах незалежного регіону» спрямована на дослідження фінансової стійкості підприємства, шляхів іiі досягнення в умовах формування незалежного регіону в Україні. Метою статті $\epsilon$ проаналізувати фінансову стійкість підприємства як складову економічної стійкості незалежного регіону. У роботі застосовувалась сукупність методів дослідження, що становить методологію аналізу та організації основних публікацій, законодавчих актів та законів, а саме методи узагальнення, порівняння, хронологізації, аналізу та узагальнення. Використовується складна система фінансових перетворень у вигляді пелюсткової діаграми з використанням маркерів за допомогою програми Microsoft Excel. У статті розглядається поняття «економічної стійкості», що дозволяє повноцінно осягнути значення фінансової стійкості підприємства, як невід'ємної іiі складової, в умовах автономного регіону. Доведено значущість соціальної стійкості в структурі економічної стійкості, як центрального і найважливішого фактору формування бізнесу та економіки держави. Результатами дослідження стали висновки, зроблені на основі дослідження наукової та законодавчої бази досліджень 3 даної проблематики, а також формування основних напрямів підвищення фінансової стійкості на основі соціальної стійкості, що i утворило наукову новизну в сфері економічних досліджень. Практичну значущість наукового дослідження та його результатів становить фінансовий аналіз ринку продовольчих товарів, як основний показник добробуту населення, оскільки формування соціуму є основною ланкою на яку спрямовується пропозиція будь якого ринку. Це i $є$ основа формування незалежного регіону в центрі організації якого є потреба людини в соціально-економічних благах. Запропоновано поглибити дослідження в напряму соціальної стійкості як одного 3 основних чинників впливу на економічну стійкість підприємства.
\end{abstract}

Ключові слова: фінансова стійкість, незалежний регіон, ринок продуктових товарів харчування. 


\title{
DIRECTIONS INCREASING FINANCIAL SUSTAINABILITY OF ENTERPRISES IN THE CONDITIONS INDEPENDENT REGION
}

\author{
Pavlo Tychyna Uman State Pedagogical University, \\ Ministry of Education and Science of Ukraine, \\ Department of Finance, Accounting and Economic Security, \\ Sadova str., 2, Uman, \\ 20300, Ukraine, \\ tel.: 067-7729730, \\ e-mail: melnichyk_yuliya@ukr.net
}

\begin{abstract}
The article "Directions Increasing Financial Sustainability of Enterprises in the Conditions Independent Region” at studying the financial sustainability of the enterprise, ways to achieve it in an independent region in Ukraine. The purpose of the article is to analyze the financial sustainability of the enterprise as a component of the economic sustainability of the independent region. The set of research methods was used in the work, which is the methodology of analysis and organization of major publications, legislation and laws, namely the methods of generalization, comparison, chronology, analysis and generalization. A complex system of financial transformations in the form of a petal chart using markers using Microsoft Excel is used. The article considers the concept of "economic sustainability", which allows us to fully understand the importance of financial sustainability of the enterprise, as an integral part of it, in an autonomous region. The importance of social sustainability in the structure of economic sustainability as a central and most important factor in the formation of business and the state economy is proved. The results of the study were the conclusions made on the basis of research of scientific and legislative base of research on this issue, as well as the formation of the main directions of increasing financial sustainability on the basis of social sustainability, which formed a scientific novelty in economic research. The practical significance of scientific research and its results is the financial analysis of the food market as a key indicator of welfare, as the formation of society is the main link to which the supply of any market. This is the basis for the formation of an independent region at the center of which is the human need for socioeconomic benefits. It is proposed to deepen research in the direction of social sustainability as one of the main factors influencing the economic sustainability of the enterprise.
\end{abstract}

Key words: financial sustainability, independent region, food market.

Introduction. Regardless of the economic situation, the country is experiencing the development of market relations, which is accompanied by the active formation of entrepreneurship, the creation of new enterprises in the food industry and even in regions that form independent economic conditions. However, such a business is characterized by low economic sustainability. Therefore, the financial analysis of economic processes at the enterprise level and in-depth study of economic processes related to their activities is important not only in the process of market relations, but especially in the period of formation of an independent region. This is where there is an urgent need to make management decisions aimed at improving the financial sustainability of the enterprise, which can be ensured only through professional financial analysis of the enterprise, carried out using a number of economic and financial indicators calculated on the basis of financial statements and additional accounting indicators enterprise. At this stage of management there is a need to deeply determine the existing capabilities of the enterprise to achieve and maintain sustainable and effective business development. And most importantly - the achievement of positive results in solving problems by enterprises affects economic sustainability at all other levels of management of the production process.

Scientists are constantly dealing with the issue of financial sustainability, which confirms the relevance of this issue. In the works of Melnychuk Y., Baranovsky A., 
Vinichenko I., Dymchenko V., Mudraka R.P., Levitsky V., Raitsky K., Sukhorukova T., Suvorova V., Tkachenko S.M., Popova K., Khrushchev N., covers issues related to solving the complex economic problem of increasing financial sustainability and finding factors influencing it.

Since financial sustainability is a component of economic stability, the study should start with general definitions.

Tkachenko S.M. notes that the problem of determining the economic sustainability of enterprises of any form of ownership as a category of management process to ensure it is not yet fully explored. And despite the fact that today this concept has already been introduced into the economic practice of enterprises, in general, the essence of economic sustainability has not been studied [1]. It is worth agreeing with the scientist, because the issues of economic analysis of the sustainability of enterprises can be dealt with only by knowledgeable professionals, which are so lacking in modern enterprises, so in fact, business may be vulnerable in a crisis.

Current trends in socio-economic development of society determine the focus of enterprises on achieving economic sustainability. Increased requirements for sustainable production and economic, financial and economic and organizational and managerial activities of enterprises require the development and implementation of effective approaches to enterprise management, among which the main place belongs to social management and development strategies. Because the introduction of the social component in the overall process of enterprise management will contribute to its development in parallel with increasing its economic sustainability [2]. Man is at the center of everything. Therefore, meeting the needs of society is the main task of any business. And the human factor must be taken into account when evaluating the activities of the enterprise.

Under economic sustainability, various authors understand a complex, complex concept, as well as economic activity itself. There are dozens of definitions of economic sustainability in different editions. "Economic" means a creative process that produces good or meets the needs of a person or business entity. Hence, economic sustainability can be used to characterize the entities engaged in economic activities, the results of these activities and its consequences for the subject and for its environment [3].

Setting objectives. Examining the financial sustainability of food companies, it should be noted that this characteristic of the activity contains a wide range of indicators that reveal and synthesize the effectiveness of other components of financial stability of the company, especially the amount and structure of own funds, level of profitability and return on equity, observance of the established liquidity indicators, efficiency of the own capital, volume of the created added value, profitability, liquidity and other important indicators. Maintaining financial sustainability by the enterprise allows to maintain competitiveness in the food production market and economic efficiency of the enterprise as a whole. However, this is a very difficult task.

Results. Having analyzed the approaches to the economic category of the concept of "economic sustainability ", we propose to consider the economic sustainability of the food enterprise as [4]:

- reflection of the state of equilibrium of the enterprise;

- an interconnected set of structural elements that are united by a common goal;

- maximum rational use of own potential;

- ability to react and resist internal and external negative factors;

- the state of the enterprise, where the most optimal management system for stable and progressive development of the food enterprise is formed.

Management in the formation of an independent region requires the introduction and use of modern tools for managing the resource potential of enterprises, where a special role is 
played by the formation and strengthening of intellectual and human resources of the enterprise as a prerequisite for ensuring its economic sustainability [2]. Therefore, the importance of ensuring the personnel, social and communication components of the economic sustainability of the enterprise increases. Based on the fact that the crisis affects not only the sphere of entrepreneurship, but also all spheres of economic relations, and most importantly the social sphere, we propose to take into account the following structural elements of economic sustainability for the food company (Fig. 1).

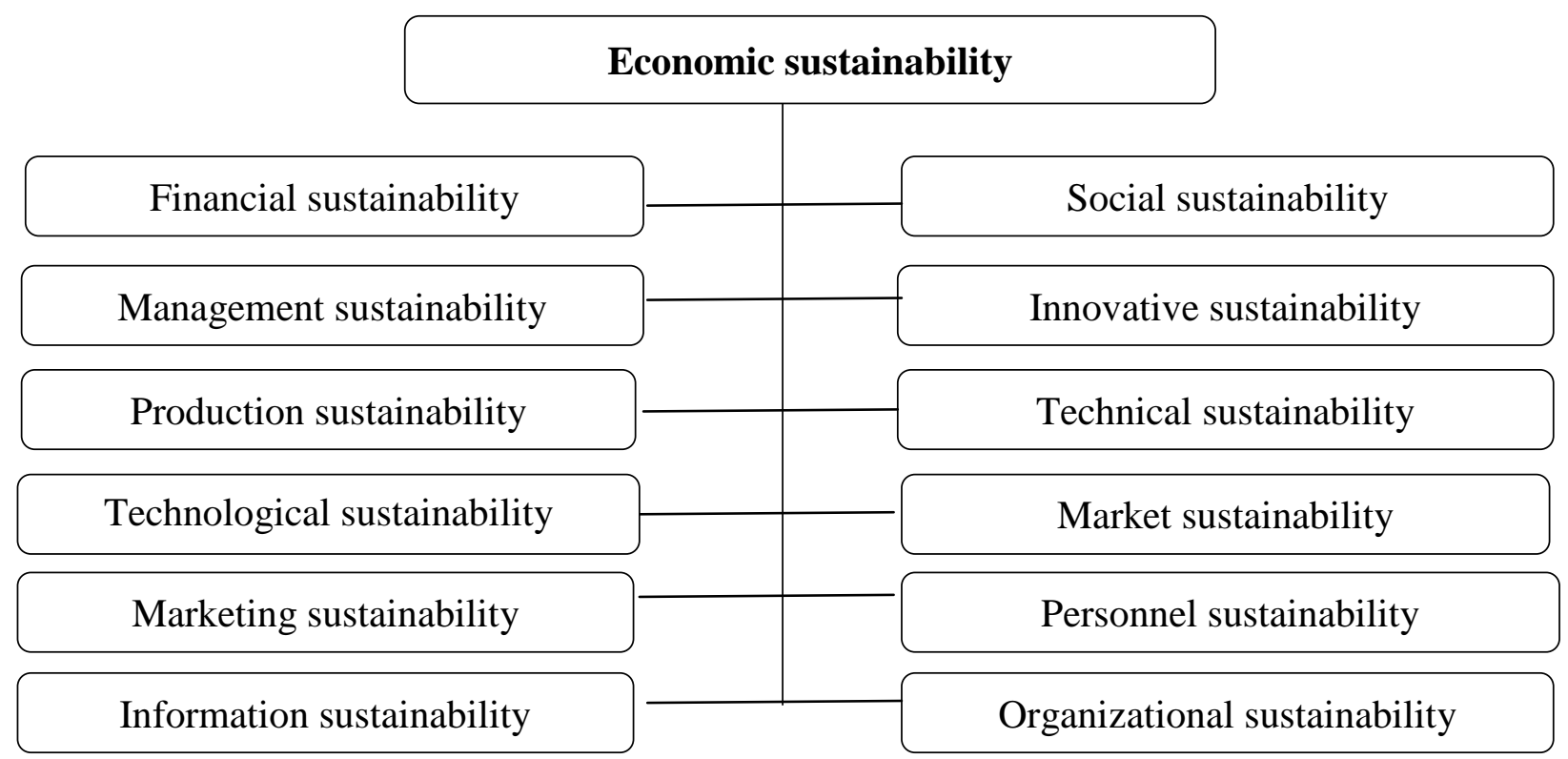

Fig. 1. Structural elements of economic sustainability of the food enterprise * * own development

The analysis of each component of economic sustainability of the food enterprise is especially important analysis and demands experience of experts at the enterprise, it will help in administrative decisions and will provide reduction of risks. After analyzing the approaches of scientists to this issue, we concluded that the most influential and important is social sustainability.

Since the food industry involved in shaping the export potential of our country can have a positive impact on Ukraine's economic growth, it is a priority in ensuring the economic security of the country and achieving high national competitiveness of the country. It should also be noted that the importance of the food industry for the economy of our country is due to the amount of tax revenues it provides [5].

Consider the volume of products sold by the food industry of Ukrainian enterprises in 2019, the results are shown in Fig. 2. 


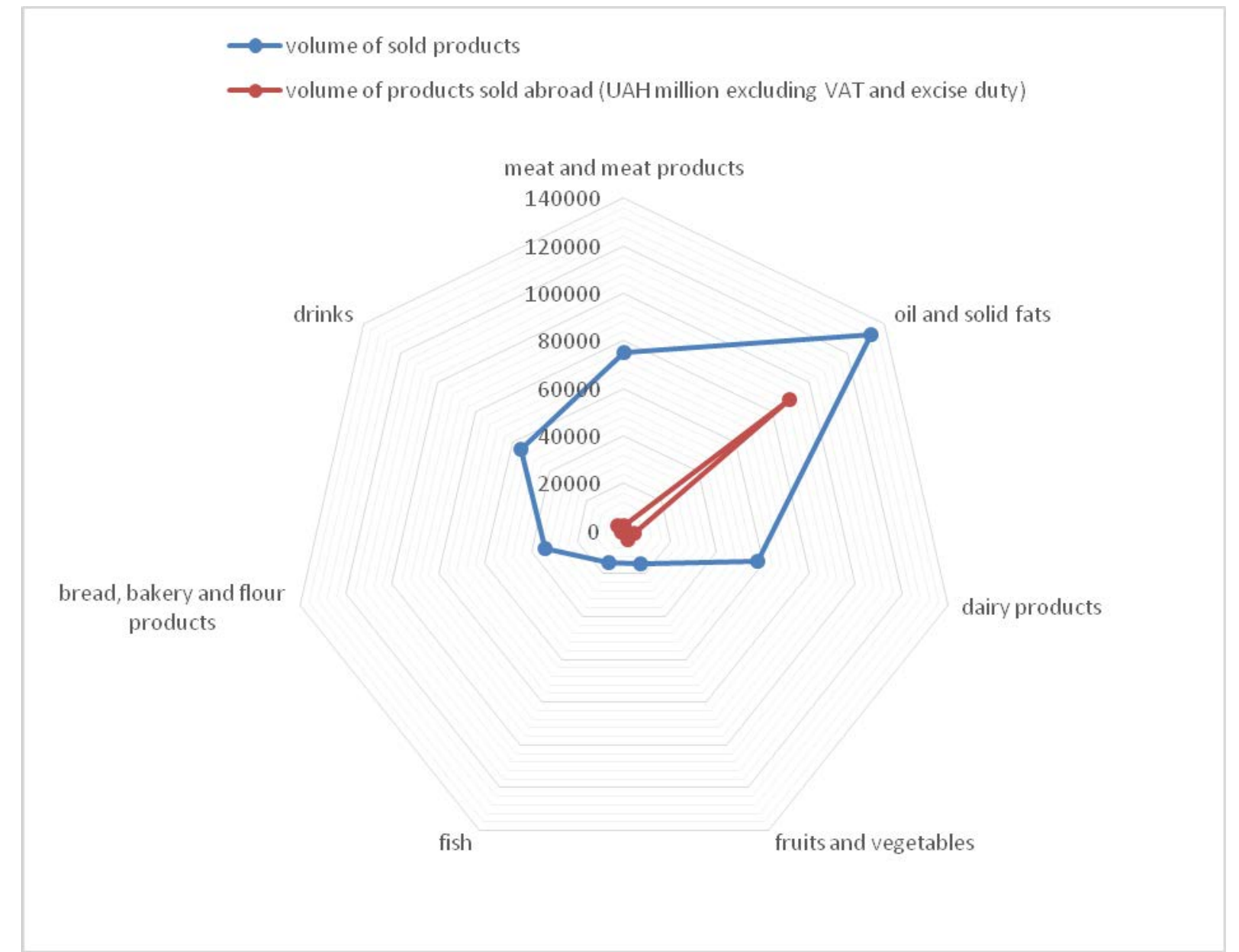

Fig. 2. The volume of products sold by the food industry by Ukrainian enterprises in 2019, UAH million *

* developed by the author according to [6]

Considering the structure of food production in Ukraine, we observe the level of demand for food. Yes, we see that oil and fats, meat and meat products, dairy products occupy the first places in the field of nutrition. In order to identify problematic factors influencing the economic sustainability of the food enterprise, it is necessary to analyze the state of food sales during the economic crisis, it will reveal the real picture of demand for products in times of economic decline (Fig. 3). 


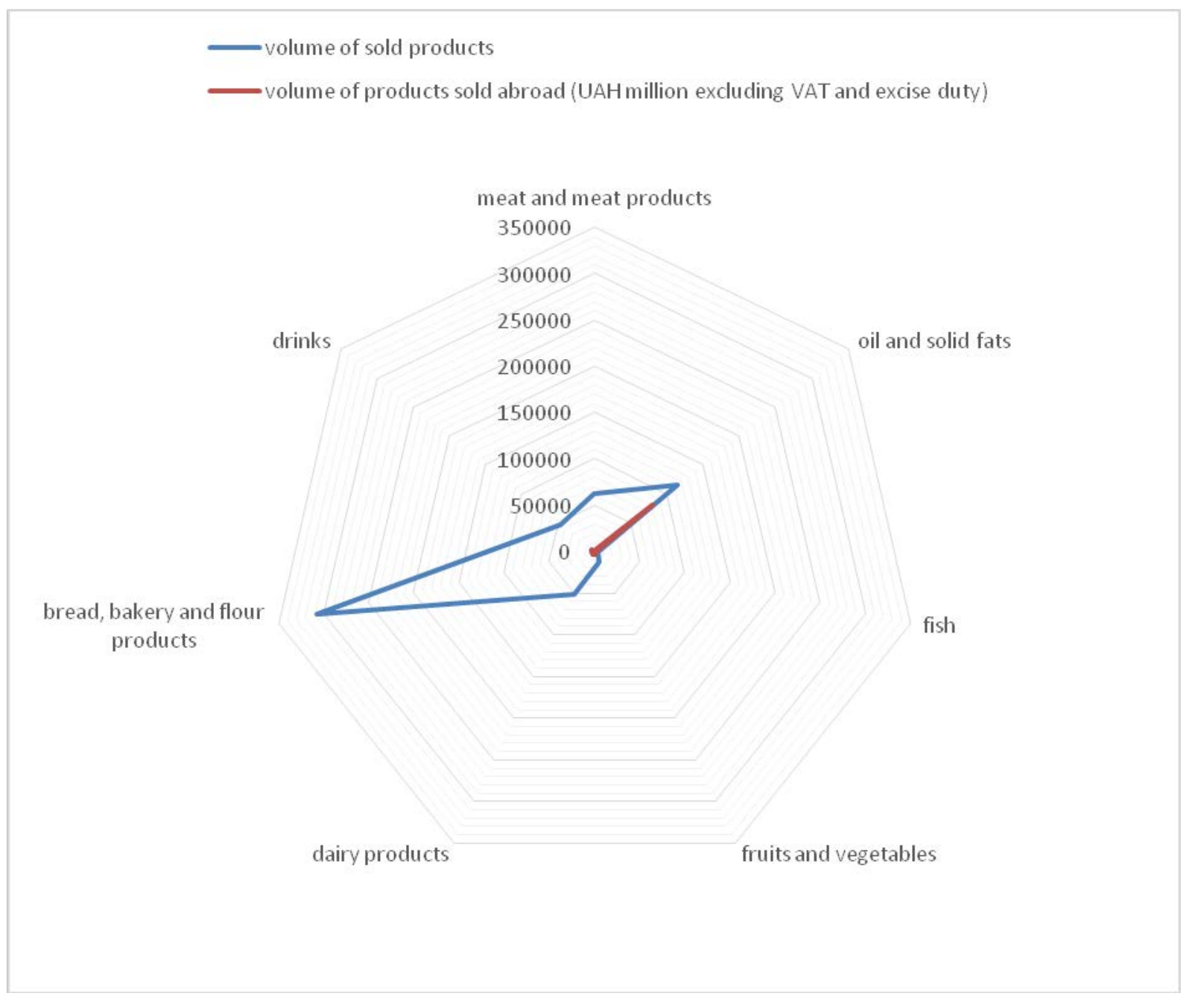

Fig. 3. The volume of products sold by the food industry by enterprises of Ukraine in 2016 during the economic crisis, UAH million *

* developed by the author according to [6]

Observations and analysis showed that during the economic crisis, the most in demand were essential products, namely, bread, bakery and flour products. Improving demand for a variety of food products in 2019 indicates the country's exit from the economic crisis and allows scientists to analyze and identify a number of factors that may affect the state of food production. Also create models of prevention, that is anti-crisis models, of crisis situations.

Consider the issue of changes in production of the main types of food industry products, indicators and calculations of growth rates are shown in Table 1. 
Change in the volume of production of basic food products industry

\begin{tabular}{|l|l|l|l|l|l|}
\hline \multirow{2}{*}{ group of goods } & \multicolumn{5}{|c|}{ growth rates, \% } \\
\cline { 2 - 6 } & $2005 / 2004$ & $2010 / 2009$ & $2015 / 2014$ & $2017 / 2016$ & $2019 / 2018$ \\
\hline nutrition products: & 17,5 & 10,7 & 44,4 & 8,5 & 13,4 \\
\hline $\begin{array}{l}\text { bread and bakery } \\
\text { products }\end{array}$ & $-1,1$ & 12,3 & 60,6 & 11,1 & 8,4 \\
\hline $\begin{array}{l}\text { meat and meat } \\
\text { products }\end{array}$ & 30,3 & 2 & 31,3 & 7,3 & 20,9 \\
\hline $\begin{array}{l}\text { fish and fish } \\
\text { products }\end{array}$ & 29,8 & 5,1 & 60,2 & 5,1 & 1,7 \\
\hline $\begin{array}{l}\text { milk, cheese and } \\
\text { eggs }\end{array}$ & 23,4 & 21,9 & 28,5 & 14,1 & 20,8 \\
\hline oil and fats & 24 & 9,6 & 45,5 & 13,4 & 15,4 \\
\hline fruits & 20,6 & 5,1 & 72,4 & $-1,8$ & 15,2 \\
\hline vegetables & $-8,3$ & 14,5 & 30,8 & $-6,4$ & 10,3 \\
\hline sugar & 27,5 & 57,5 & 36 & 17,8 & 6,8 \\
\hline
\end{tabular}

*Calculated on the basis of data [6]

According to the results of calculations, during the crisis in the country business is beginning to decline in accordance with the declining solvency of the population, but nutrition plays an important role in the social sphere, and requires in-depth study. Figure 4 shows the dynamics of the growth rate of food production [7].

According to Fig. 4 we see that 2015 is reflected in a significant jump in growth rates, this is due to the fact that previous years were declining in this area, and a sharp change in production was reflected in an increase in growth rates this year.

Keep in mind that the model of increasing the financial sustainability of the enterprise consists of a set of elements that are closely interrelated. At the heart of all components is the need for a person-centered, and therefore social sphere, which is a very important criterion [8]. 


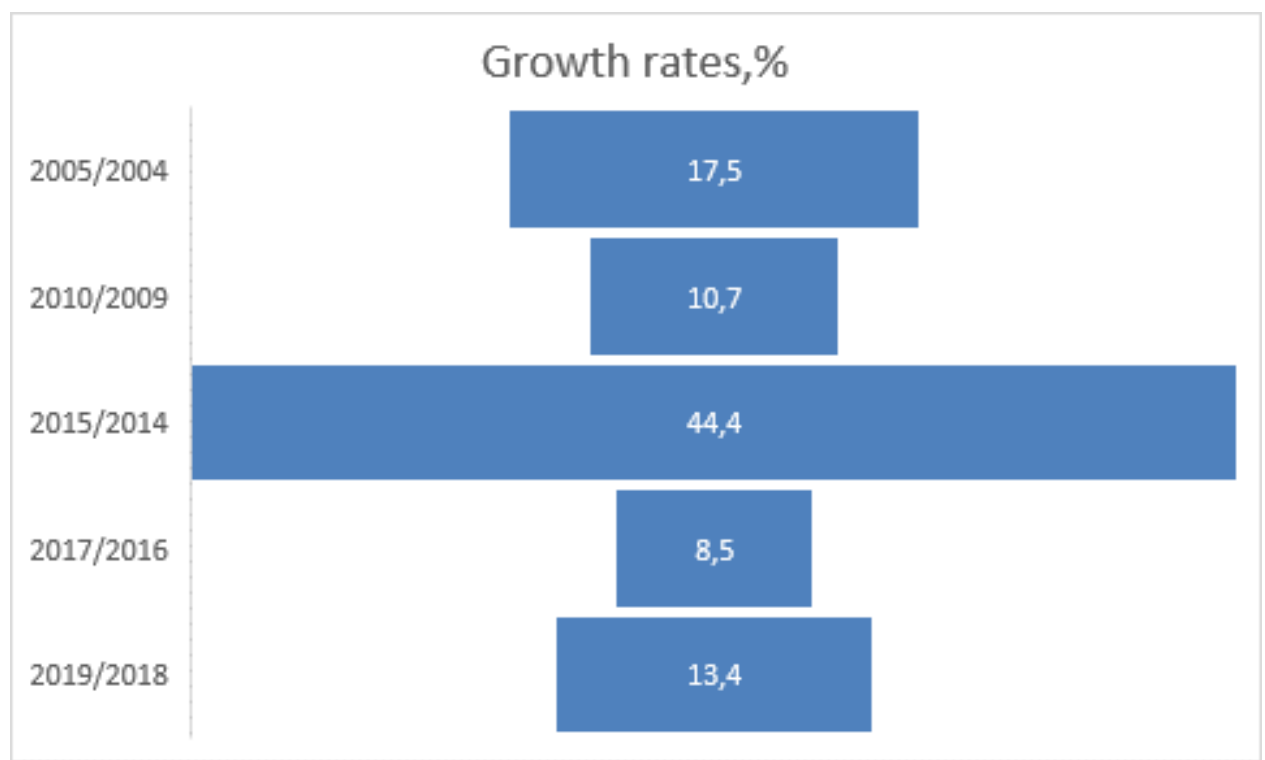

Fig. 4. Dynamics of growth rates of food production,\%

* Developed on the basis of data [6]

When a business is socially oriented to meet human needs, it will meet two effects: on the one hand - to increase demand for products, on the other - to increase sales.

Conclusions. Thus, in the conditions of formation of an independent region, the search for increasing the financial sustainability of the enterprise is an urgent and necessary component of the process of overcoming the crisis not only at the micro but also at the macro level. Since most companies do not have a social orientation of business, and the lack of skilled workers necessitates the creation of a new socially oriented system to increase the financial sustainability of the food company based on social development strategies. Such a system must contain the following elements:

- employment policy, should cover all possible measures aimed at providing the company with highly qualified personnel, creating the necessary working conditions, ensuring the guarantor of occupational safety, career growth and wage growth;

- training policy, which provides all possible measures to improve the skills of employees and encourage the pursuit of professional growth;

- remuneration policy, which includes elements of a sufficiently high salary in the ratio of experience-ability-devotion, benefits, incentives, etc.

Ensuring the social needs of labor will lead workers to work hard and, accordingly, will solve the accompanying problems of economic sustainability of the food enterprise: improving the quality of manufactured products, continuity of production, low or zero shortages, losses, crime, and so on. However, savings on employees is a way to reduce the economic stability of the enterprise.

Foreign experience shows that increasing financial sustainability in the formation of an independent region can be ensured by increasing the competitiveness of enterprises by introducing incentives to reduce production costs by reducing shortages and, accordingly, the cost of production, the use of alternative energy sources; introduction of international quality standards; application of measures aimed at the development of small food production business as one of the main areas of job creation and income growth during the formation of an independent region.

1. Ткаченко С. М. Сутність економічної стійкості підприємств та ії складові. Ефективна економіка. 2011. № 5. URL: http://www.economy.nayka.com.ua/?op=1\&z=1350 (дата звернення 30.10.2020) 
Актуальні проблеми розвитку економіки регіону. Вип 16. T.2

2. Левицький В. Розроблення системи підвищення економічної стійкості підприємства на основі соціальних стратегій розвитку підприємства. Будуємо нову Україну. 2010. №3. С. 238-245. URL: http://ekmair.ukma.edu.ua/bitstream/handle/123456789/4598/Levyts\%27kyy_Rozroblennya_systemy. pdf?sequence $=1$ \&isAllowed=y (дата звернення 30.10.2020)

3. Вініченко І., Крючок С. Економічна стійкість підприємства та ії складові. Агросвіт. 2016. № 24. URL: file:///C:/Users/Lenovo\%20S145/Downloads/agrosvit_2016_24_4.pdf (дата звернення 30.10.2020)

4. Melnychuk Yu. M. Application of systematic approaches to assessing the effectiveness of the bank in conditions of financial independence of the region. Economies' Horizons. 2019. № 1(8). p. 36-43. URL: http://eh.udpu.edu.ua/article/view/170023 (дата звернення 30.10.2020)

5. Державна служба статистики. Індекси промислової продукції. URL: http://www.ukrstat.gov.ua/ (дата звернення 30.10.2020)

6. Краснолуцька О.В. Аналіз функціонування та тенденцій організаційного розвитку харчової промисловості України. Економіка та управління національним господарством. 2019. №3 (14). C. 66-70.

7. Ткачук І.Г., Мельничук Ю.М. Господарський механізм мікрорівневого стратегічного розвитку незалежного регіону. Актуальні проблеми розвитку регіону. 2019. Вип. 15., Т. 2., с. 140-147.

8. Melnychuk Yu., Chyrva O.H., Chvertko L. A., Chyrva H.M., Berbets V.V. The Role of Management in the Financial Independence of the Region. Tem Journal. 2019. Vol. 8. (2). pp. 584-590.

\section{References}

1. Tkachenko, S. M. "The essence of economic stability of enterprises and its components." Efektyvna Ekonomika, 2011, www.economy.nayka.com.ua/?op=1\&z=1350 Accessed 30 Oct. 2020.

2. Levytskyi, V. "Development of a system for increasing the economic stability of the enterprise on the basis of social strategies for enterprise development.” Buduiemo Novu Ukrainu, no.3, 2010, pp. 238245.

ekmair.ukma, ekmair.ukma.edu.ua/bitstream/handle/123456789/4598/Levyts\%27kyy_Rozroblennya_systemy.pdf?s equence=1\&isAllowed=yAccessed 30 Oct. 2020.

3. Vinichenko, I. \& S.Kriuchok (). "Economic stability of the enterprise and its components". Ahrosvit, no.24, 2016, agrosvit_2016_24_4.pdf. Accessed 30 Oct. 2020.

4. Melnychuk, Yu. M. "Application of systematic approaches to assessing the effectiveness of the bank in conditions of financial independence of the region.” Economies' Horizons, no.1(8), 2019, pp. 36-43. eh.udpu, eh.udpu.edu.ua/article/view/170023. Accessed 30 Oct. 2020.

5. "Industrial production indices." State Statistics Service, www.ukrstat.gov.ua/Accessed 30 Oct. 2020.

6. Krasnolutska, O.V. "Analysis of the functioning and trends of organizational development of the food industry of Ukraine.” Ekonomika Ta Upravlinnia Natsionalnym Hospodarstvom, no. 3 (14), 2019, pp. 66-70.

7. Tkachuk, I.H. \& Yu.M.Melnychuk ."Economic mechanism of micro-level strategic development of the independent region.” Aktualni Problemy Rozvytku Rehionu, no. 15 (2), 2019, pp. 140-147.

8. Melnychuk, Yu., Chyrva, O.H., Chvertko, L. A., Chyrva, H.M., and V.V. Berbets. "The Role of Management in the Financial Independence of the Region.” Tem Journal, no.8. (2), 2019, pp. 584590.

УДК 338.242

doi: 10.15330/apred.2.16.178-188

\section{ОСНОВНІ НАПРЯМИ ДЕРЖАВНОЇ ПІДТРИМКИ ЕКОЛОГІЗАЦЇ̈ СІЛЬСЬКОГО ГОСПОДАРСТВА}

Уманський національний університет садівництва, Міністерство освіти і науки України, кафедра економіки, вул. Інститутська, 1, м. Умань, 20305,Україна, тел.: (04744) 3-22-26, 